\title{
Growth and Associated Factors in Children and Adolescents Living with HIV/AIDS Followed at the Mother and Child Centre of the Chantal Biya Foundation, Yaoundé-Cameroon: A Case Control Study
}

\author{
David Chelo ${ }^{1,2 *}$, Eulalie Landrine Moguon Fondjo ${ }^{3}$, Pierre Fotsing Kwetche ${ }^{3}$, \\ Séraphin Nguefack ${ }^{2,4}$, Félicitée Nguefack ${ }^{2,4}$, Suzanne Ngo Um ${ }^{1,2}$, Georges Nguefack Tsague \\ ${ }^{1}$ Mother and Child Centre, Chantal BIYA Foundation, Yaoundé, Cameroon \\ ${ }^{2}$ Department of Pediatrics, Faculty of Medicine and Biomedical Sciences, University of Yaoundé 1, Yaoundé, Cameroon \\ ${ }^{3}$ Faculty of Health Sciences, Banganté, Cameroon \\ ${ }^{4}$ Gyneco-Obstetric and Pediatric Hospital, Yaoundé, Cameroon \\ ${ }^{5}$ Department of Public Health, Faculty of Medicine and Biomedical Sciences, University of Yaoundé 1, Yaoundé, Cameroon \\ Email: *chelodad6@yahoo.fr
}

How to cite this paper: Chelo, D., Fondjo, E.L.M., Kwetche, P.F., Nguefack, S., Nguefack, F., Um, S.N. and Tsague, G.N. (2020) Growth and Associated Factors in Children and Adolescents Living with HIV/AIDS Followed at the Mother and Child Centre of the Chantal Biya Foundation, Yaoundé-Cameroon: A Case Control Study. Open Journal of Pediatrics, 10, 194-205. https://doi.org/10.4236/ojped.2020.101019

Received: February 7, 2020

Accepted: March 21, 2020

Published: March 24, 2020

Copyright $\odot 2020$ by author(s) and Scientific Research Publishing Inc. This work is licensed under the Creative Commons Attribution International License (CC BY 4.0).

http://creativecommons.org/licenses/by/4.0/ (c) (i) Open Access

\begin{abstract}
Background: HIV/AIDS has a negative impact on child growth. Assessing the growth of infected children is an important part of the overall care of these children which in turn improves the monitoring and prognosis of the disease. The purpose of the study was to describe and compare the growth of children living with HIV with those not infected and to identify the associated factors. Method: This was an analytical case control study conducted in a pediatric hospital, Yaoundé from January $25^{\text {th }}$ to June $20^{\text {th }} 2019$. Our study population consisted of 164 children with an age range from 06 weeks to 19 years old of which we had $41 \mathrm{HIV}$-infected cases and 123 uninfected controls matched by sex and age plus or minus 02 months. Anthropometric parameters were measured according to the standards described by the WHO. The data was entered and analyzed using Epi info 3.5.4, WHO Anthro and WHO Anthropoplus softwares. The chi-square and the Fisher's exact tests were used to compare qualitative variables, with a significance threshold set at P less than 5\%. Results: Of the 41 cases, 15 (36.6\%) had at least one anthropometric index (weight for age, height for age, weight for height) $<-2$ $\mathrm{Z}$ score versus 05 for controls (4.1\%). 36.6\% of cases had growth retardation (Height for age $<-2 \mathrm{Z}$ score) compared to $4.1 \%$ in controls with a significant difference $(p=0.000)$. In $18.2 \%$ of cases, underweight was found (Weight for
\end{abstract}


age $<-2 \mathrm{Z}$ score) with a significant difference compared to controls ( $p=$ $0.000)$. Wasting was present in $10 \%$ of infected children $(P=0.240)$. We found $7.3 \%$ obesity/overweight in cases and $25.2 \%$ in controls $(P=0.003)$. We did not find any associated factor with growth disorders in our study. Conclusion: Infected children are smaller in weight and size. After multivariate analysis, there remained a significant difference between cases and controls regarding stunting, obesity and overweight. No factors studied were associated with the growth disorders detected, which suggests that growth disorders in children and adolescents living with HIV are due to the disease itself. Hence the need for health workers is to strengthen the prevention of mother and child transmission and the monitoring of the growth of HIV-infected children in order to improve the long-term prognosis.

\section{Keywords}

Growth, HIV/AIDS, Child, Adolescent, Yaoundé

\section{Introduction}

In Africa, HIV/AIDS is a major cause of infant and child mortality and morbidity. West and Central Africa have a significant proportion of the world's population of children aged 0 - 14 years living with HIV [1]. Growth and metabolic abnormalities are common in children living with HIV [2]. Stunting is a major manifestation of HIV infection and an independent risk factor of children's death. According to WHO, it accounts for $60 \%$ of all manifestations of HIV/AIDS in children, with a significant effect on long-term survival [3]. HIV infection is associated with nutritional deficiencies and malnutrition affects the progression of the disease, increasing morbidity and mortality of these children. Assessing the growth of infected children is an important part of the overall care of these children and thus improves follow-up and prognosis. The purpose of the study was to describe and compare the growth of children living with HIV with those not infected and to identify the associated factors.

\section{Method}

It was a case-control analytical study from January to June 2019, conducted in the unit specialized in the care of children infected with HIV at the Mother and Child Centre of the Chantal BIYA Foundation. This Centre has the largest cohort of HIV-positive children in the city of Yaounde. The HIV/AIDS component is highly developed with a significant follow-up activity for infected and exposed children.

We recruited 164 children with ages ranging from 06 weeks to 19 years. There were 41 cases and 123 controls. At the day hospital, cases were identifiable by the pink colour of their files. They were approached before or after medical consultations, pychological consultations or while collecting drugs. We then recruited 
controls who were HIV/AIDS negative with respect to the inclusion criteria. Some controls came for routine consultations or vaccination, while others came or were brought from the community for screening in the hospital. Each case was matched with 3 controls with respect to sex and age with an interval of more or less 2 months between the two groups. In order to ensure a good size compatible with different statistical analyzes, the calculation of the minimum sample size was made from of Schlesselman's formula. This gave a minimal of 30 cases for 90 controls.

Clinical evaluations were carried out on these children to collect data concerning the past history, clinical and biological stages of the disease. Parents' and children's sociodemographic data was collected and anthropometric parameters (weight, height, mid upper arm circumference) were measured using the WHO standards [4].

Observance to treatment was evaluated as follows:

- Calculated observance: [number of tablets effectively taken/number of tablets to be taken] ${ }^{\star} 100$.

- Declared observance: respect of schedule, 1 missed medication within the past four days, or missed medications within a week since treatment initiation.

A patient was declared observant to treatment if the calculated observance was $\geq 95 \%$, respect of schedule and no missed medications.

The nutritional status was evaluated using:

- Infant and Child Feeding Index (ICFI) for children $<03$ years, having nine points and graded as low status $(<5)$, moderate $(5-7)$ and high $(>7)$.

- Individual Dietary Diversity Score (IDDS) for children $\geq 03$ years with a total of eight points graded as low status (0 - 3), moderate (4 - 5) and high (6 - 8).

The socioeconomic status was graded as low (0 - 2), moderate (3 - 5), or high $(>5)$. This was graded using a questionnaire established by the national statistics institute of Cameroon consisting of the characteristics and equipment of the household.

\subsection{Definitions}

Stunting was defined using the H/A index, underweight was defined using the $\mathrm{W} / \mathrm{A}$ index, wasting was defined using the $\mathrm{W} / \mathrm{H}$ index were all fixed at a $\mathrm{Z}$ score $<-2$.

Overweight was defined as a BMI/A between 2 - $3 \mathrm{Z}$ score.

Obesity was defined as a $\mathrm{BMI} / \mathrm{A}>3 \mathrm{Z}$ score.

\subsection{Ethical Considerations}

We obtained ethical clearance from the ethical committee of Universite des Montagnes as well as research authorisations from the Mother and Child Centre of the Chantal Biya Foundation. The parents/tutors gave their free and informed consent before data collection. 


\subsection{Statistical Analysis}

Data was entered and analysed using the Epi info 3.5.4, WHO Anthro and WHO Anthro poplus softwares. The chi square and Fisher's exact tests were used to compare qualitative variables with a significance threshold set at $P<5 \%$. An odds ratio with its confidence interval of $95 \%$ was used to test for association of variables. A conditional logistic regression was carried out to eliminate any confusion factors.

\section{Results}

We recruited 164 patients. The most represented age group was between 10 and 19 years, representing $46.3 \%$ of the population with a feminine majority at $53.7 \%$. Of the registered cases, more than half (63\%) were at clinical stage 1 and biological stage 1 of the disease.

The nutritional status of the two groups of children according to the different anthropometric indices has been represented in Table 1.

Table 1. Distribution of the population according to the different anthropometric indices.

\begin{tabular}{|c|c|c|c|c|}
\hline & \multicolumn{2}{|c|}{ Group } & \multirow[b]{2}{*}{ Adjusted OR (95\% CI) } & \multirow[b]{2}{*}{$\mathrm{P}$-value } \\
\hline & Cases & Controls & & \\
\hline Variables & n (\%) & n (\%) & & \\
\hline \multicolumn{5}{|c|}{ Stunting } \\
\hline \multicolumn{5}{|c|}{$\mathrm{N} 1=41, \mathrm{~N} 2=123$} \\
\hline Yes & $15(36.6)$ & $5(4.1)$ & $14.13(4.39-61.38)$ & $<0.001$ \\
\hline No & $26(63.4)$ & $118(95.9)$ & 1 & - \\
\hline \multicolumn{5}{|c|}{ Underweight } \\
\hline \multicolumn{5}{|c|}{$\mathrm{N} 1=22, \mathrm{~N} 2=66$} \\
\hline Yes & $4(18.2)$ & $0(0)$ & - & $<0.001$ \\
\hline No & $18(81.8)$ & $66(100)$ & - & - \\
\hline \multicolumn{5}{|c|}{ Wasting } \\
\hline \multicolumn{5}{|c|}{$\mathrm{N} 1=10, \mathrm{~N} 2=32$} \\
\hline Yes & $1(10)$ & $0(0)$ & - & 0.240 \\
\hline No & $9(90)$ & $32(100)$ & - & - \\
\hline \multicolumn{5}{|l|}{ Obesity } \\
\hline \multicolumn{5}{|c|}{$\mathrm{N} 1=41, \mathrm{~N} 2=123$} \\
\hline Yes & $0(0)$ & $6(4.9)$ & - & 0.170 \\
\hline No & $41(100)$ & $117(95.1)$ & & \\
\hline \multicolumn{5}{|c|}{ Obesity/Overweight } \\
\hline Yes & $3(7.3)$ & $31(25.2)$ & $0.14(0.02-0.59)$ & 0.003 \\
\hline No & $38(92.7)$ & $92(74.8)$ & 1 & - \\
\hline
\end{tabular}

N1: total counts of cases, N2: total counts of controls. 
Stunting was found in $36.6 \%$ of cases against $4.1 \%$ of controls with statistical significance $(P<0.001)$. Underweight was found in $18.2 \%$ of cases with a significant difference between cases and controls. Wasting was present in $10 \%$ of cases and absent in the control group. Obesity/overweight was present in $7.3 \%$ of cases against $25.2 \%$ of controls with a significant difference $(p=0.003)$.

\section{Factors associated with growth impairment in infected children}

The association between anthropometric indices (H/A, W/A) and the mother's socio-demographic factors such as age, marital status, occupation and academic status has been studied and represented in Table 2 and Table 3.

No maternal socio demographic factor was significantly linked to stunting and underweight in infected children.

Table 4 and Table 5 represent child factors and anthropometric indices.

The biological stage $3(\mathrm{OR}=3, P=0.2)$, low nutritional status $(\mathrm{OR}=2.8, P=$ $0.14)$, a past history of gastroenteritis $(\mathrm{OR}=2.8, P=0.14)$ and a high viral load $(\mathrm{OR}=1.53, P=0.43)$ exposed to stunting. However, there was no significant association between child-linked factors and stunting (Table 4).

Table 2. Maternal-related factors and H/A index in infected children.

\begin{tabular}{|c|c|c|c|c|c|}
\hline & \multicolumn{2}{|c|}{ Stunting } & \multirow[b]{2}{*}{ Total } & \multirow[b]{2}{*}{ OR (95\% CI) } & \multirow[b]{2}{*}{ P-value } \\
\hline & Yes & No & & & \\
\hline & $\mathrm{N}=12$ & $N=17$ & & & \\
\hline Variables & n (\%) & n (\%) & n (\%) & & \\
\hline \multicolumn{6}{|l|}{ Mother's age } \\
\hline$[20-34]$ & $5(41.7)$ & $7(58.3)$ & $12(41.4)$ & $1.02(0.21-4.79)$ & 0.640 \\
\hline$>34$ & $7(41.2)$ & $10(58.8)$ & $17(58.6)$ & $0.98(0.21-4.71)$ & 0.640 \\
\hline \multicolumn{6}{|l|}{ Marital status } \\
\hline Divorced/Widow & $1(100)$ & $0(0)$ & $1(3.4)$ & - & 0.410 \\
\hline Concubinage & $7(53.8)$ & $6(46.2)$ & $13(44.8)$ & $2.57(0.53-12.4)$ & 0.200 \\
\hline Single & $2(28.6)$ & $5(71.4)$ & $7(24.1)$ & $0.48(0.06-3.1)$ & 0.370 \\
\hline Married & $2(25)$ & $6(75)$ & $8(27.6)$ & $0.37(0.04-2.27)$ & 0.250 \\
\hline \multicolumn{6}{|l|}{ Mother's occupation } \\
\hline Student & $0(0)$ & $1(100)$ & $1(3.4)$ & $0(0-26.92)$ & 0.590 \\
\hline Private sector & $2(50)$ & $2(50)$ & $4(13.8)$ & $1.5(0.14-16.2)$ & 0.560 \\
\hline Trader & $2(50)$ & $2(50)$ & $4(13.8)$ & $1.5(0.14-16.2)$ & 0.560 \\
\hline Unemployed & $4(44.4)$ & $5(55.6)$ & $9(31)$ & $1.2(0.22-6.22)$ & 0.570 \\
\hline Informal sector/Peasant/Retired & $4(50)$ & $4(50)$ & $8(27.6)$ & $1.63(0.28-9.07)$ & 0.430 \\
\hline Public sector & $0(0)$ & $3(100)$ & $3(10.3)$ & $0(0-2.35)$ & 0.190 \\
\hline \multicolumn{6}{|l|}{ Mother's academic status } \\
\hline None/primary & $2(25)$ & $6(75)$ & $8(27.6)$ & $0.37(0.04-2.27)$ & 0.250 \\
\hline Secondary & $9(50)$ & $9(50)$ & $18(62.1)$ & $2.67(0.51-15.52)$ & 0.210 \\
\hline Higher & $1(33.3)$ & $2(66.7)$ & $3(10.3)$ & $0.68(0.02-10.08)$ & 0.630 \\
\hline
\end{tabular}


Table 3. Maternal-related factors and W/A index in infected children.

\begin{tabular}{|c|c|c|c|c|c|}
\hline & \multicolumn{2}{|c|}{ Underweight } & & \multirow[b]{3}{*}{ OR $(95 \% \mathrm{CI})$} & \multirow[b]{3}{*}{ P-valu } \\
\hline & $\mathrm{N}=4$ & $N=16$ & & & \\
\hline & Yes & No & Total & & \\
\hline Variables & n (\%) & n (\%) & $\mathrm{n}(\%)$ & & \\
\hline \multicolumn{6}{|l|}{ Mother's age } \\
\hline$[20-34]$ & $3(30)$ & $7(70)$ & $10(50)$ & $3.86(0.31-111.94)$ & 0.290 \\
\hline$>34$ & $1(10)$ & $9(90)$ & $10(50)$ & $0.26(0.01-3.18)$ & 0.290 \\
\hline \multicolumn{6}{|l|}{ Marital status } \\
\hline Concubinage & $3(27.3)$ & $8(72.7)$ & $11(55)$ & $3(0.25-88.17)$ & 0.370 \\
\hline Single & $1(14.3)$ & $6(85.7)$ & $7(35)$ & $0.56(0.02-6.72)$ & 0.560 \\
\hline Married & $0(0)$ & $2(100)$ & $2(10)$ & $0(0-14.88)$ & 0.630 \\
\hline \multicolumn{6}{|l|}{ Occupation of mother/tutor } \\
\hline Student & $0(0)$ & $1(100)$ & $1(5)$ & $0(0-76)$ & 0.800 \\
\hline Private sector & $1(33.3)$ & $2(66.7)$ & $3(15)$ & $2.33(0.06-38.65)$ & 0.510 \\
\hline Trader & $0(0)$ & $3(100)$ & $3(15)$ & $0(0-7.48)$ & 0.490 \\
\hline Unemployed & $2(28.6)$ & $5(71.4)$ & $7(35)$ & $2.2(0.18-25.44)$ & 0.440 \\
\hline Informal sector/Peasant/Retired & $1(20)$ & $4(80)$ & $5(25)$ & $1(0,03-12,65)$ & 0.720 \\
\hline Public sector & $0(0)$ & $1(100)$ & $1(5)$ & $0(0-76)$ & 0.800 \\
\hline \multicolumn{6}{|l|}{ Mother's academic status } \\
\hline None/primary & $0(0)$ & $7(100)$ & $7(35)$ & $0(0-1.92)$ & 0.150 \\
\hline Secondary & $4(36.4)$ & $7(63.6)$ & $11(55)$ & - & 0.070 \\
\hline Higher & $0(0)$ & $2(100)$ & $2(10)$ & $0(0-14.88)$ & 0.630 \\
\hline
\end{tabular}

Biological grade $3(\mathrm{OR}=5.67, P=0.34)$, low nutritional status $(\mathrm{OR}=7.8, P=$ $0.12)$, gastroenteritis $(\mathrm{OR}=3.5, P=0.29)$ and an elevated viral load $(\mathrm{OR}=5, P=$ 0.2 ) exposed to underweight. Nevertheless, there was no association between child-related factors and underweight (Table 5).

\section{* Household factors and anthropometric indices}

Household factors analyzed were in regards to the person in charge of the child, number of children in the household, socioeconomic status. A low socioeconomic status exposed to stunting in infected children but no child-related factor was associated with neither stunting nor underweight in these children.

\section{Discussion}

This study had as main aim to compare the growth of children infected with HIV to those not infected and to find associated factors.

Underweight $(\mathrm{W} / \mathrm{A}<-2)$ was found in $18.2 \%$ of cases with statistical significance $(P=0.000)$ compared to controls of which none had a W/A index $<-2$. HIV and opportunistic infections cause metabolic and nutritional disorders especially protein hyper catabolism as well as intestinal absorption alteration which could be the causes of the underweight found in our series. Infections are 
Table 4. Infected children-related factors and H/A.

\begin{tabular}{|c|c|c|c|c|c|}
\hline & \multicolumn{2}{|c|}{ Stunting } & \multirow[b]{2}{*}{ Total } & \multirow[b]{2}{*}{ OR $(95 \% \mathrm{CI})$} & \multirow[b]{2}{*}{$P$-value } \\
\hline & Yes & No & & & \\
\hline & $\mathrm{N}=15$ & $\mathrm{~N}=26$ & & & \\
\hline Variables & n (\%) & $\mathrm{n}(\%)$ & n (\%) & & \\
\hline \multicolumn{6}{|l|}{ Child's sex } \\
\hline Masculine & $9(47.4)$ & $10(52.6)$ & $19(46.3)$ & $2.4(0.63-9.2)$ & 0.160 \\
\hline Feminine & $6(27.3)$ & $16(72.7)$ & $22(53.7)$ & $0.42(0.11-1.58)$ & 0.160 \\
\hline \multicolumn{6}{|l|}{ Feeding Mode } \\
\hline Exclusive breastfeeding & $7(41.2)$ & $10(58.8)$ & $17(41.5)$ & $1.4(0.37-5.22)$ & 0.430 \\
\hline Mixed feeding & $4(25)$ & $12(75)$ & $16(39)$ & $0.42(0.1-1.71)$ & 0.180 \\
\hline Artificial feeding & $4(57.1)$ & $3(42.9)$ & $7(17.1)$ & $2.79(0.48-16.85)$ & 0.210 \\
\hline \multicolumn{6}{|l|}{ Disease's clinical stage } \\
\hline Stage 1 & $7(26.9)$ & $19(73.1)$ & $26(63.4)$ & $0.32(0.08-1.28)$ & 0.090 \\
\hline Stage 2 & $6(46.2)$ & $7(53.8)$ & $13(31.7)$ & $1.81(0.44-7.19)$ & 0.300 \\
\hline Stage 3 & $2(100)$ & $0(0)$ & $2(4.9)$ & - & 0.130 \\
\hline \multicolumn{6}{|l|}{ Disease's biological stage } \\
\hline Stage 1 & $8(30.8)$ & $18(69.2)$ & $26(63.4)$ & $0.51(0.13-1.98)$ & 0.250 \\
\hline Stage 2 & $4(40)$ & $6(60)$ & $10(24.4)$ & $1.21(0.25-5.41)$ & 0.540 \\
\hline Stage 3 & $3(60)$ & $2(40)$ & $5(12.2)$ & $3(0.39-27.32)$ & 0.250 \\
\hline \multicolumn{6}{|l|}{ Viral load (copies/ml) } \\
\hline \multicolumn{6}{|l|}{$<40$} \\
\hline Yes & $5(27.8)$ & $13(72.2)$ & $18(43.9)$ & $0.5(0.12-1.92)$ & 0.240 \\
\hline No & $10(43.5)$ & $13(56.5)$ & $23(56.1)$ & & \\
\hline \multicolumn{6}{|l|}{] $40-100,000[$} \\
\hline Yes & $6(42.9)$ & $8(57.1)$ & $14(34.1)$ & $1.5(0.37-5.81)$ & 0.390 \\
\hline No & $9(33.3)$ & $18(66.7)$ & $27(65.9)$ & & \\
\hline \multicolumn{6}{|l|}{$\geq 100,000$} \\
\hline Yes & $4(44.4)$ & $5(55.6)$ & $9(22)$ & $1.53(0.3-7.2)$ & 0.430 \\
\hline No & $11(34.4)$ & $21(65.6)$ & $32(78)$ & & \\
\hline \multicolumn{6}{|l|}{ Nutrient intakes } \\
\hline Low level & $6(54.5)$ & $5(45.5)$ & $11(26.8)$ & $2.8(0.64-12.2)$ & 0.140 \\
\hline Medium level & $9(32.1)$ & $19(67.9)$ & $28(68.3)$ & $0.55(0.14-2.26)$ & 0.300 \\
\hline High level & $0(0)$ & $2(100)$ & $2(4.9)$ & $0(0-6.03)$ & 0.400 \\
\hline \multicolumn{6}{|l|}{ Treatment compliance } \\
\hline Yes & $5(31.3)$ & $11(68.8)$ & $16(39)$ & $0.68(0.17-2.62)$ & 0.410 \\
\hline No & $10(40)$ & $15(60)$ & $25(61)$ & & \\
\hline \multicolumn{6}{|l|}{ Child's history } \\
\hline \multicolumn{6}{|l|}{ Bronchopneumonia } \\
\hline Yes & $3(37.5)$ & $5(62.5)$ & $8(19.5)$ & $1.05(0.18-5.38)$ & 0.630 \\
\hline No & $12(36.4)$ & $21(63.6)$ & $33(80.5)$ & & \\
\hline \multicolumn{6}{|l|}{ Gastroenteritis } \\
\hline Yes & $6(54.5)$ & $5(45.5)$ & $11(26.8)$ & $2.8(0.64-12.2)$ & 0.140 \\
\hline No & $9(30)$ & $21(70)$ & $30(73.2)$ & & \\
\hline \multicolumn{6}{|l|}{ Otitis } \\
\hline Yes & $0(0)$ & $2(100)$ & $2(4.9)$ & $0(0-6.03)$ & 0.400 \\
\hline No & $15(38.5)$ & $24(61.5)$ & $39(95.1)$ & & \\
\hline \multicolumn{6}{|l|}{ Tuberculosis } \\
\hline Yes & $1(50)$ & $1(50)$ & $2(4.9)$ & $1.79(0.04-72.24)$ & 0.600 \\
\hline No & $14(35.9)$ & $25(64.1)$ & $39(95.1)$ & & \\
\hline
\end{tabular}


Table 5. Infected children-related factors and W/A.

\begin{tabular}{|c|c|c|c|c|c|}
\hline & \multicolumn{2}{|c|}{ Underweight } & \multirow[b]{3}{*}{ Total } & \multirow[b]{3}{*}{ OR $(95 \% \mathrm{CI})$} & \multirow[b]{3}{*}{ P-valu } \\
\hline & $\mathrm{N}=4$ & $\mathrm{~N}=18$ & & & \\
\hline & Yes & No & & & \\
\hline Variables & n (\%) & n (\%) & $\mathrm{n}(\%)$ & & \\
\hline \multicolumn{6}{|l|}{ Child's sex } \\
\hline Masculine & $3(23.1)$ & $10(76.9)$ & $13(59.1)$ & $2.4(0.2-70.58)$ & 0.450 \\
\hline Feminine & $1(11.1)$ & $8(88.9)$ & $9(40.9)$ & $0.42(0.01-4.89)$ & 0.450 \\
\hline \multicolumn{6}{|l|}{ Feeding Mode } \\
\hline Exclusive breastfeeding & $2(18.2)$ & $9(81.8)$ & $11(50)$ & $1(0.09-11.42)$ & 0.710 \\
\hline Mixed feeding & $1(12.5)$ & $7(87.5)$ & $8(36.4)$ & $0.52(0.02-6.15)$ & 0.530 \\
\hline Artificial feeding & $1(33.3)$ & $2(66.7)$ & $3(13.6)$ & $2.67(0.07-43.7)$ & 0.470 \\
\hline \multicolumn{6}{|l|}{ Disease's clinical stage } \\
\hline Stage 1 & $1(8.3)$ & $11(91.7)$ & $12(54.5)$ & $0.21(0.01-2.57)$ & 0.230 \\
\hline Stage 2 & $2(22.2)$ & $7(77.8)$ & $9(40.9)$ & $1.57(0.13-17.75)$ & 0.550 \\
\hline Stage 3 & $1(100)$ & $0(0)$ & $1(4.5)$ & - & 0.180 \\
\hline \multicolumn{6}{|l|}{ Disease's biological stage } \\
\hline Stage 1 & $1(8.3)$ & $11(91.7)$ & $12(54.5)$ & $0.21(0.01-2.57)$ & 0.230 \\
\hline Stage 2 & $2(25)$ & $6(75)$ & $8(36.4)$ & $2(0.17-22.61)$ & 0.470 \\
\hline Stage 3 & $1(50)$ & $1(50)$ & $2(9.1)$ & $5.67(0.11-232.28)$ & 0.340 \\
\hline \multicolumn{6}{|l|}{ Viral load (copies/ml) } \\
\hline \multicolumn{6}{|l|}{$<40$} \\
\hline Yes & $0(0)$ & $9(100)$ & $9(40.9)$ & $0(0-1.45)$ & 0.100 \\
\hline No & $4(30.8)$ & $9(69.2)$ & $13(59.1)$ & & \\
\hline \multicolumn{6}{|l|}{] $40-100,000[$} \\
\hline Yes & $2(25)$ & $6(75)$ & $8(36.4)$ & $2(0.17-22.61)$ & 0.470 \\
\hline No & $2(14.3)$ & $12(85.7)$ & $14(63.6)$ & & \\
\hline \multicolumn{6}{|l|}{$\geq 100,000$} \\
\hline Yes & $2(40)$ & $3(60)$ & $5(22.7)$ & $5(0.36-59.85)$ & 0.210 \\
\hline No & $2(11.8)$ & $15(88.2)$ & $17(77.3)$ & & \\
\hline \multicolumn{6}{|l|}{ Nutrient intakes } \\
\hline Low level & $3(37.5)$ & $5(62.5)$ & $8(36.4)$ & $7.8(0.61-219.3)$ & 0.120 \\
\hline Medium level & $1(7.7)$ & $12(92.3)$ & $13(59.1)$ & $0.17(0.01-2.07)$ & 0.170 \\
\hline High level & $0(0)$ & $1(100)$ & $1(4.5)$ & $0(0-85.5)$ & 0.820 \\
\hline \multicolumn{6}{|l|}{ Treatment compliance } \\
\hline Yes & $1(12.5)$ & $7(87.5)$ & $8(36.4)$ & $0.52(0.02-6.15)$ & 0.530 \\
\hline No & $3(21.4)$ & $11(78.6)$ & $14(63.6)$ & & \\
\hline \multicolumn{6}{|l|}{ Child's history } \\
\hline \multicolumn{6}{|l|}{ bronchopneumonia } \\
\hline Yes & $0(0)$ & $3(100)$ & $3(13.6)$ & $0(0-8.51)$ & 0.530 \\
\hline No & $4(21.1)$ & $15(78.9)$ & $19(86.4)$ & & \\
\hline \multicolumn{6}{|l|}{ Gastroenteritis } \\
\hline Yes & $2(33.3)$ & $4(66.7)$ & $6(27.3)$ & $3.5(0.27-40.45)$ & 0.290 \\
\hline No & $2(12.5)$ & $14(87.5)$ & $16(72.7)$ & & \\
\hline \multicolumn{6}{|l|}{ Otitis } \\
\hline Yes & $0(0)$ & $1(100)$ & $1(4.5)$ & $0(0-85.5)$ & 0.820 \\
\hline No & $4(19)$ & $17(81)$ & $21(95.5)$ & & \\
\hline \multicolumn{6}{|l|}{ Tuberculosis } \\
\hline Yes & $0(0)$ & $1(100)$ & $1(4.5)$ & $0(0-85.5)$ & 0.820 \\
\hline No & $4(19)$ & $17(81)$ & $21(95.5)$ & & \\
\hline
\end{tabular}


usually associated with anorexia leading to decrease in food intake. Similar findings were found in Malawi and America [5] [6].

Stunting $(\mathrm{H} / \mathrm{A}<-2)$ is frequent among HIV infected children [7]. We found $36.6 \%$ of infected children presenting with stunting with a significant difference compared to the control group $(P=0.000)$. Several authors suggest the presence of a hormonal disorder (growth hormone, thyroid hormones) linked to HIV in the occurrence of growth retardation although there is a lack of consensus [8] [9] [10]. We however did not check for hormonal variations in our study. Authors in Ivory Coast found $66.6 \%$ of stunting, almost twice that found in our study (36.6\%). This discrepancy could be explained by the fact that the former's studies were on already malnourished children [11].

With regards to the Weight/Height index, $10 \%$ of infected children had a $\mathrm{Z}$ score $<-2$ against $0 \%$ in the non-infected group though no significant difference $(P=0.24)$ probably due to the small sample size $(\mathrm{n}=10)$. This index is linked to acute malnutrition because in case of nutritional or infectious problems, it rapidly alters. Due to consequences of the natural evolution of HIV such as chronic inflammation, increase in energy requirements and inadequate food intake to ensure normal growth, weight loss is thus a main complication of the disease. The rate is lower in our population compared to that found in Congo at $20.5 \%$ [12]. Children in our study were on treatment with lower clinical stages and were followed up in a structure where their nutritional management was capital with counseling offered to parents/tutors daily and could thus explain this contrast.

We found $7.3 \%$ of obese/overweight cases against $25.2 \%$ controls with statistical significance. The body mass index is one of the main components used in evaluating body fats. It indirectly estimates the fatty tissue component of the body. Some authors stipulate that in HIV infected children, a reduction in growth rate can be due to the decrease in the lean mass as a consequence of hyper catabolism [8]. An increase in cytokines such as TNF- $\alpha$ due to chronic inflammation leads to anorexia which causes undernutrition [8]. In Cameroon, a study carried out in 2012 did not find any obese child amongst those infected. These children did not benefit from a nutritional management, hence the observation.

Among cases concerning the Height/Age index: the biological stage $3(\mathrm{OR}=3$, $P=0.2)$ and low nutritional status $(\mathrm{OR}=2.8 P=0.14)$ exposed to stunting. As for the weight/age index: the biological stage $3(\mathrm{OR}=5.67 P=0.34)$, low nutritional status $(\mathrm{OR}=7.8 P=0.12)$ and high viral load $(\mathrm{OR}=5 P=0.2)$ exposed to underweight. Howeverno maternal, child or household factors were significantly associated with growth disorders.

Authors in America nevertheless found high viral loads, high interleukine-6 (IL-6) activity, low serum protein levels, low CD4 counts, low insulin-like growth factor-1 (IGF-1), a past history of pneumonia, low level of maternal education, anaemia and diarrheoa to be associated with growth disorders in infected children [6] [13] [14]. Meanwhile in Cameroon, other authors [15] found oropha- 
ryngeal candidoses to be associated to severe malnutrition in seropositive children. These discrepancies observed can be because the authors carried out cohort studies with larger sample sizes and thus could better identify the associations of different factors and growth disorders.

\section{Limits of the Study}

Our first limit was the study design chosen (case control study) which is restrictive and not allowing adequate study of the association between factors and the different phenomena. Also, the ICFI score used to evaluate the nutritional intake in children less than 03 years has a section requiring the use of memory for events 7 days prior to the day of data collection and thus constitutes a bias. Finally, it would have been more instructive to quantify nutritional intake as well as evaluate the energy contents.

\section{Conclusion}

Children living with HIV are smaller in weight and height. They have significant growth disorders compared to non infected children with respect to the H/A, $\mathrm{W} / \mathrm{A}$ and $\mathrm{BMI} / \mathrm{A}$ indices. There is no association between nutritional intake, observance to treatment, socioeconomic status, stages of the disease, maternal factors and the development of growth disorders. Growth disorders in children and adolescents living with HIV are due to the disease itself. Thus, there is a necessity for health personnel to rigorously continue the fight against mother to child transmission as well as the follow up of staturo-ponderal growth of HIV infected children with the aim of ameliorating the long term survival rate of children born of seropositive mothers.

\section{Funding}

There was no funding.

\section{Availability of Data and Materials}

The datasets generated and/or analyzed during the current study are not publicly available due to exclusively scientific purpose use, but are available from the corresponding author on reasonable request.

\section{Authors' Contributions}

Study concept and design: DC, GNT, PFK. Literature review DC, GNT, ELMF. Data collection and interpretation: DC, ELMF, FN; Statistical analysis ELMF, FN, PFK. Writing DC, ELMF. Review DC, GNT, SN, FN. Study supervision: DC, GNT. All authors read and approved the final manuscript.

\section{Conflicts of Interest}

The authors declare that they have no competing interests. 


\section{References}

[1] United Nations of International Children's Emergency Fund (2017) Step-Up the Pace: Towards an AIDS-Free Generation in West and Central Africa.

[2] Oleske, J., Minnefor, A., Cooper, R., Thomas, K., dela Cruz, A., Ahdieh, H., et al. (1983) Immune Deficiency Syndrome in Children. JAMA, 249, 2345-2349. https://doi.org/10.1001/jama.249.17.2345

[3] Rubinstein, A., Sicklick, M., Gupta, A., Bernstein, L., Klein, N., Rubinstein, E., et al. (1983) Acquired Immunodeficiency with Reversed T4/T8 Ratios in Infants Born to Promiscuous and Drug-Addicted Mothers. JAMA, 249, 2350-2356. https://doi.org/10.1001/jama.249.17.2350

[4] Cogill, B. (2003) Guide de mesure des indicateurs anthropométriques: Projet d'Assistance Technique pourl'Alimentation et la Nutrition. Académie pour le Développementde l'Education, Washington DC.

[5] Sherr, L., Hensels, I., Tomlinson, M., Skeen, S. and Macedo, A. (2018) Cognitive and Physical Development in HIV-Positive Children in South Africa and Malawi: A Community-Based Follow-Up Comparison Study. Child: Care, Health and Development, 44, 89-98. https://doi.org/10.1111/cch.12533

[6] Miller, T., Easley, K., Zhang, W., Orav, E., Bier, D., Luder, E., et al. (2001) Maternal and Infant Factors Associated with Failure to Thrive in Children with Vertically Transmitted Human Immunodeficiency Virus-1 Infection: The Prospective, P2C2 Human Immunodeficiency Virus Multicenter Study. Pediatrics, 108, 1287-1296. https://doi.org/10.1542/peds.108.6.1287

[7] Chiabi, A., Lebela, J., Kobela, M., Mbuagbaw, L., Obama, M. and Ekoe, T. (2012) The Frequency and Magnitude of Growth Failure in a Group of HIV-Infected Children in Cameroon. Pan African Medical Journal, 11, 15.

[8] Arpadi, S. (2005) Growth Failure in HIV-Infected Children: Consultation on Nutrition and HIV/AIDS in Africa.

[9] Geffner, M., Yeh, D. and Landaw, E. (1993) In Vitro Insulin-Like Growth Factor-I, Growth Hormone, and Insulin Resistance Occurs in Symptomatic Human Immunodeficiency Virus-I-Infected Children. Pediatric Research, 34, 66-72. https://doi.org/10.1203/00006450-199307000-00016

[10] Lepage, P., Msellati, P., Hitimana, D., Bazubagira, A., Van Goethem, C., Simonon, A., et al. (1996) Growth of Human Immunodeficiency Type 1-Infected and Uninfected Children: A Prospective Cohort Study in Kigali, Rwanda, 1988 to 1993. Pediatric Infectious Disease Journal, 15, 479-485. https://doi.org/10.1097/00006454-199606000-00003

[11] Beau, J. and Imboua-Coulibaly, L. (1997) Caractéristiques anthropométriques d'enfants malnutris infectés par le VIH en Côte d'Ivoire. Cahiers Santé, 7, 236-238.

[12] Mwadianvita, C., Kanyenze, F., Wembonyama, C., Mutomb, F., Mupoya, K., Nkoy, A., et al. (2014) Etat nutritionnel des enfants âgés de 6 à 59 mois infectés par le VIH mais non traités aux ARV à Lubumbashi. Pan African Medical Journal, 19, 7. https://www.ncbi.nlm.nih.gov

[13] Johann-Liang, R., O’Neill, L., Cervia, J., Haller, I., Giunta, Y., Licholai, T., et al. (2000) Energy Balance, Viral Burden, Insulin-Like Growth Factor-1, Interleukin-6 and Growth Impairment in Children Infected with Human Immunodeficiency Virus. Aids, 14, 683-690. https://doi.org/10.1097/00002030-200004140-00007

[14] Villamor, E., Fataki, M., Bosch, R., Mbise, R. and Fawzi, W. (2004) Human Immunodeficiency Virus Infection, Diarrheal Disease and Sociodemographic Predictors 
of Child Growth. Acta Paediatrica, 93, 372-379.

https://doi.org/10.1111/j.1651-2227.2004.tb02964.x

[15] Penda, C., Moukoko, E., Nolla, N., Evindi, N. and Ndombo, P. (2018) Malnutrition among HIV Infected Children under 5 Years of Age at the Laquintinie Hospital Douala, Cameroon. Pan African Medical Journal, 30, 91.

https://www.ncbi.nlm.nih.gov

\section{Abbreviations}

WHO: World Health Organization

ICFI: Infant Child Food Intake

IDDS: Individual Dietary Diversity Score

HIV: Human Immunodeficiency Virus

AIDS: Acquired Immunodeficiency Syndrome

BMI: Body Mass Index

W: Weight

H: Height

A: Age 